\title{
ブロック図を用いた製造プロセスのシミュレーション技法の開発*
}

滝沢 龍一"1, 北沢 俊二*1

\section{Manufacturing Process Simulation Method by Using Block Diagram}

\author{
Ryuichi TAKIZAWA *1 and Syunji KITAZAWA \\ ${ }^{* 1}$ Nagano Prefecture General Industrial Technology Center \\ Wakasato 1-18-1, Nagano-shi, Nagano, 380-0928 Japan
}

An easy simulation method makes it possible to introduce an environment-conscious manufacturing process. By considering the production flow to the mass flow, a process can be described as a block which calculates from in and out cost ratio. The manufacturing process can be described in a block diagram by connecting these blocks. The block diagram is turned into one block by equivalent transformations. It facilitates the comparison of cost at a manufacturing process change. And it is able to apply to $\mathrm{CO} 2$ emissions of a manufacturing process, too. This paper proposes the idea of a simple method to calculate costs and $\mathrm{CO} 2$ emissions on the process change.

Key Words : Environment Conscious, Manufacturing Process, MFCA, Block Diagram, Cost, CO2 Emissions, Equivalent Transformation, Process Change

\section{1. 緒言}

近年，発達した人類の文明が地球環境に良い影響を与えていないことが明らかになりつつあり，全ての社会活 動において環境負荷を低減していくことは人類共通の課題であると言っても過言ではない，製造業においても例 外ではなく，環境に配慮したものづくりを行うことが急務の課題となっている.

製造業では原料調達から廃棄，再利用まで製品のライフサイクル全般を考慮して環境負荷低減を目指寸環境配 慮設計 ${ }^{(1)}$ という考え方を取り入れることが一般的である.この概念を具体化するために製品アセスメントのチェ ックリストやLife Cycle Assessment (LCA)といった手法が広く用いられている(2)(3)(4)(5) . 製品アセスメントのチェッ クリストは，各要求項目について「はい・いいえ」という答えを積み重初て定性的な評価を行うため，製造現場 で導入しやすい. より詳しく評価するために, 重み付けを行って定量化する手法も提案されている(6). また, LCA では製品ライフサイクルの各段階において環境負荷要因を明らかにすることができ, 数值で負荷の大きさを知る ことができる(7)。これらの手法は製品を主体とした評価手法であり, 製造プロセス内の個々の工程は見えない形 で計算を行うため, 各工程の変更による効果を実感しにくい. また, 製造工程の環境負荷低減のための研究はい くつか行われているが(8)(9)，工程の変化に着目した研究はほとんど行われていない.

実際の製造現場では環境配慮設計の第一段階として, 省エネ設備の導入や廃棄物のリサイクルなど製造工程を 変更することから実施していく例が多い(10)(11)(12). また，企業として経費削減は恒常的な課題であるため，製造プ ロセス変更時のコストまたは製造原価の比較も必要である．製造プロセス設計者および工場責任者が環境配慮型 の製造プロセスを設計，導入する際に，個々の工程の変更が既存製造プロセスの原価及び環境負荷側面にどのよ うな影響を与えるのかを容易に試算する方法が求められている.

一方，製造プロセスの材料やエネルギーのロスを見える化し，工程改善につなげていくマテリアルフローコス 卜会計(Material Flow Cost Accounting : MFCA)と呼ばれる手法がある.これは1つの製造プロセスを取り上げ，投入 される物の質量を軸にして，売るものと捨てるものへどれくらいのコストがかかったかを工程毎に見える化する 手法である ${ }^{(13)}$ 。これは見方によっては工程毎に原価計算を実施していると捉えることができる. 一つの工程は

\footnotetext{
* 原稿受付 2013 年 8 月 21 日

*1 正員, 長野県工業技術総合センター（テ380-0928 長野県長野市若里 1-18-1）

E-mail: takizawa-ryuichi@pref.nagano.lg.jp
} 
前の工程から渡された原材料の原価を高めて次の工程に渡寸役割を果たしていると見なせば，これは制御工学で いう1入力1出力のブロックとして扱える．各工程をひとつのブロックで表すことができれば製造プロセスはこの ブロックをつなげたブロック図で表すことができ，さらに等価変換を行うことで各工程のブロックの係数から算 出される係数を持つより簡便なブロック図で表せる可能性がある. そこで本研究では原材料の流れを質量の流れ として捉えた形のブロック図で製造プロセスをモデル化し，工程の変更が製造プロセスのコスト及び環境負荷側 面にどのような影響を与えるかを容易に試算できるシミュレーション技法を開発することを目的とする.

\section{2. エ程のブロック化}

\section{$2 \cdot 1$ 工程の分類}

始めに原価を取り上げ，各工程のブロック化を試みる. 製造プロセスは，投入された材料をいくつかの工程を 経て製品に仕上げいてく形が一般的である.ひとつの工程では前工程から受け取った材料をその工程での所定の 処理を施して次工程に渡すという流れを実施している.この流れを原価の視点から見ると，各工程は入力された 原価にその工程の処理でかかるコストを合算し，新たな原価として次の工程に出力する働きをしていると考える ことができる．ただしここで言う原価は変動費のみを合算した值であり，固定費は考慮していない．

いま，使用する材料と捨てる材料の質量比によってコストを分配するMFCAの手法に倣い，原価を質量当たり の原価(以下単価とする)と質量の積として捉える。つまり

原価[yen]=質量当たりの原価[yen $/ \mathrm{kg}]$ ·質量 $[\mathrm{kg}]$

となる. 式(1)に基づいて原価の流れを各工程毎のブロックで表す場合, 工程前後の材料の質量変化に着目する必 要がある. 工程前後の質量変化は増加する, 減少する, 変化しないの3つのパターンに分けられるので, 以下この 3パターン別にブロック化を試みる.

\section{$2 \cdot 2$ 工程の前後で質量変化なしの場合}

まず工程の前後で材料の質量が変化しない工程Aを取り上げる. 例えば洗浄工程や熱処理工程などがこれに該 当する. 投入される材料の質量を $\mathrm{M}[\mathrm{kg}]$, 単価を $\mathrm{U}_{\mathrm{in}}[\mathrm{yen} / \mathrm{kg}]$ とすると入力原価 $\mathrm{C}_{\mathrm{in}}[\mathrm{yen}]$ は式(1) より

$$
\mathrm{C}_{\text {in }}=\mathrm{M} \cdot \mathrm{U}_{\text {in }}
$$

と表せる.

そしてMFCAに準ずる形で考えると，マテリアルコスト（水，洗剤など），エネルギーコスト（電気，灯油な ど)，システムコスト（人件費など）及び廃棄物処理コスト（排水処理費など）の各変動コストがこの工程での処 理のために必要になる. よって工程が終わったとき, 原価は入力原価にこれらのコストが加算されたものになっ ていると考えられる．従って投入されるコストの合計をC[yen]とすれば出力原価 $\mathrm{C}_{\text {out }}[\mathrm{yen}]$ は式(2)より

$$
\mathrm{C}_{\text {out }}=\mathrm{C}_{\text {in }}+\mathrm{C}=\mathrm{M} \cdot \mathrm{U}_{\mathrm{in}}+\mathrm{C}
$$

となる．これらの流れを図示すると図1のようになる．原価入出力の比を $\mathrm{K}_{\mathrm{u}}$ とすると式(2),(3)より

$$
\mathrm{K}_{\mathrm{u}}=\mathrm{C}_{\text {out }} / \mathrm{C}_{\text {in }}=\left(\mathrm{M} \cdot \mathrm{U}_{\text {in }}+\mathrm{C}\right) /\left(\mathrm{M} \cdot \mathrm{U}_{\text {in }}\right)=1+\mathrm{C} /\left(\mathrm{M} \cdot \mathrm{U}_{\text {in }}\right)
$$

\section{と表される.}

例えば洗浄工程が1回に $1 \mathrm{~kg}$ の材料 100 個を処理する能力を有している場合, 500 個の材料を処理するにはこの工 程を5回繰り返す必要がある. 従って洗剤, 水, 電気の使用量は 100 個を洗浄する場合の5倍になる. 排水も5倍と なり，また作業時間も5倍になることから，排水処理費，人件費も5倍になる．つまり， $500 \mathrm{~kg}$ の材料を処理する場 合， $100 \mathrm{~kg}$ を処理する場合の 5 倍のコストがかかることになる. ベルトコンベアなどにより一定速度で材料が流れ てくる場合についても，単位時間に区切って考えれば同様に扱うことができるため，大量生産する工程ではコス トCは投入される原材料の質量Mに比例すると言える. また, 入力原価 $\mathrm{U}_{\mathrm{in}}$ はMによる変化はないので, 式(4)より $\mathrm{K}_{\mathrm{u}}$ は入力質量に関わらず一定になる. 言い換えると工程 $\mathrm{A}$ は常に入力原価を $\mathrm{K}_{\mathrm{u}}$ 倍にして出力する働きを持つとい 


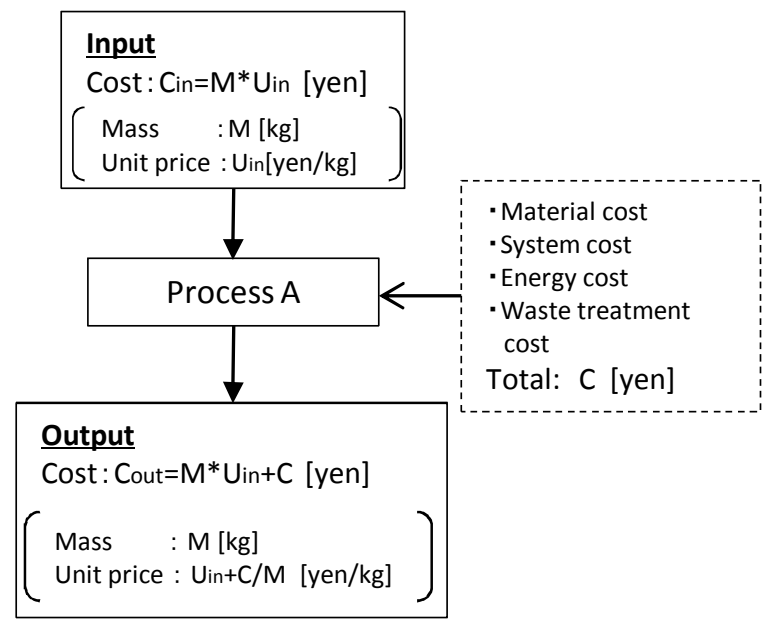

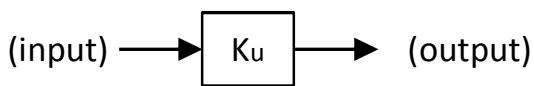

Fig2. Cost transformation block

Fig.1 Input and output for the process that has no mass change

うことができる. 従って工程Aは図2のような比例要素ブロックとして表せる. この時, 出力単価を $\mathrm{U}_{\text {out }}[\mathrm{yen} / \mathrm{kg}]$ と すると式(1),(3)より

$$
\mathrm{C}_{\text {out }}=\mathrm{M} \cdot \mathrm{U}_{\text {out }}=\mathrm{M} \cdot \mathrm{U}_{\text {in }}+\mathrm{C} \Leftrightarrow \mathrm{U}_{\text {out }}=\mathrm{U}_{\text {in }}+\mathrm{C} / \mathrm{M}
$$

となる．式(4),(5)より $\mathrm{K}_{\mathrm{u}}$ を変形すると

$$
\mathrm{K}_{\mathrm{u}}=\left(\mathrm{M} \cdot \mathrm{U}_{\text {in }}+\mathrm{C}\right) /\left(\mathrm{M} \cdot \mathrm{U}_{\text {in }}\right)=\left(\mathrm{U}_{\text {in }}+\mathrm{C} / \mathrm{M}\right) / \mathrm{U}_{\text {in }}=\mathrm{U}_{\text {out }} / \mathrm{U}_{\text {in }}
$$

となる. よって工程の前後で質量変化のない場合は材料の単価を変化させていると見なせるため，このブロック を単価変更ブロックと呼ぶことにする.

\section{$2 \cdot 3$ 工程の前後で質量が減少する場合}

次に工程の前後で質量が減少する工程Bのブロック化を試みる．質量の減少分は製品化のための正規の流れか ら分離され，別の流れとなる．例えば切りくずが発生する切削加工が代表例として挙げられるが，ロット単位の 質量で考えれば不良品を選別する検査工程もこれに該当する. 工程Bにおいても前述のマテリアル, エネルギー, システムなどのコストはかかるので，その分は出力原価に加算する必要がある. また，排除される材料はそれら のコストのかかった処理の結果として発生したと考えれば，コストをかけた後に分離していると言える．よって 工程Bはコストが付加され原価を上げる仮想工程 1 と製品と排除品を分離する仮想工程 2 のつの部分に分けられ る. この時の概要を図3に示す. 仮想工程1は工程前後の質量変化を伴わないので前述の工程 $\mathrm{A}$ と同じになり, 投 入する原材料の質量を $\mathrm{M}[\mathrm{kg}]$, 単価を $\mathrm{U}_{\mathrm{in}}[\mathrm{yen} / \mathrm{kg}]$, かかるコストを $\mathrm{C}[\mathrm{yen}]$ とすれば, 仮想工程 1 の出力原価 $\mathrm{C}_{\text {out }}[\mathrm{yen}]$ は

$$
\mathrm{C}_{\text {outl }}=\mathrm{C}_{\text {in }}+\mathrm{C}=\mathrm{M} \cdot \mathrm{U}_{\mathrm{in}}+\mathrm{C}
$$

となる. そして仮想工程1から摘出された材料が仮想工程2に投入され製品と排除品に分離される. 式(1)より原価 は単価と質量の積で表すとしたので, 仮想工程 2 では製品と排除品の質量比で原価が分離されると言い換えること ができる．製品質量を $\mathrm{M}_{1}[\mathrm{~kg}]$ ，排除品質量を $\mathrm{M}_{2}[\mathrm{~kg}]$ とすると

$$
\mathrm{M}=\mathrm{M}_{1}+\mathrm{M}_{2}
$$

の関係があり，製品側の出力原価を $\mathrm{C}_{\text {out2 }}[\mathrm{yen}]$, 排除品側の出力原価を $\mathrm{C}_{\text {out }}[\mathrm{yen}]$ とすると式(7)より 

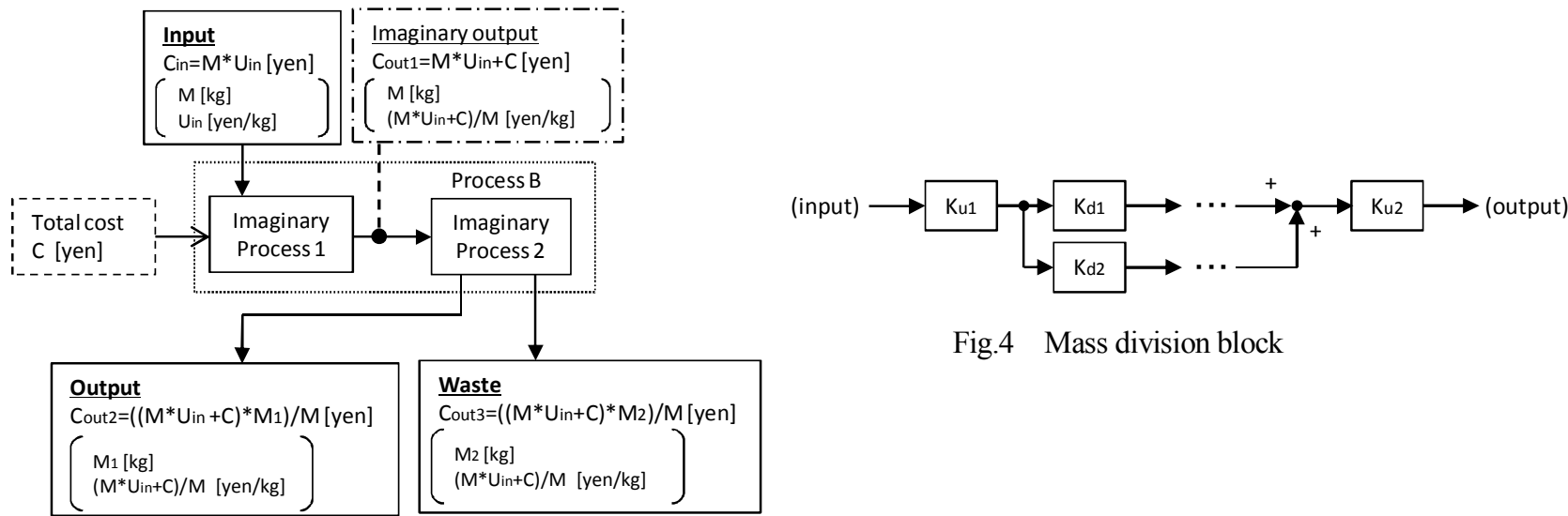

Fig.4 Mass division block

Fig3. Input and output for the process that decreases mass

$$
\begin{aligned}
& \mathrm{C}_{\text {out } 2}=\mathrm{C}_{\text {out } 1} \cdot\left(\mathrm{M}_{1} / \mathrm{M}\right)=\left(\mathrm{M} \cdot \mathrm{U}_{\text {in }}+\mathrm{C}\right) \cdot\left(\mathrm{M}_{1} / \mathrm{M}\right) \\
& \mathrm{C}_{\text {out } 3}=\mathrm{C}_{\text {out } 1} \cdot\left(\mathrm{M}_{2} / \mathrm{M}\right)=\left(\mathrm{M} \cdot \mathrm{U}_{\text {in }}+\mathrm{C}\right) \cdot\left(\mathrm{M}_{2} / \mathrm{M}\right)
\end{aligned}
$$

となる。よって仮想工程 1 表すブロックの比例係数を $\mathrm{K}_{\mathrm{u} 1}$ 仮想工程 2 のれを $\mathrm{K}_{\mathrm{d} 1}, \mathrm{~K}_{\mathrm{d} 2}$ とすると式(7),(9)より

$$
\begin{aligned}
& \mathrm{K}_{\mathrm{u} 1}=\mathrm{C}_{\text {out } 1} / \mathrm{C}_{\text {in }}=\left(\mathrm{M} \cdot \mathrm{U}_{\text {in }}+\mathrm{C}\right) / \mathrm{M} \cdot \mathrm{U}_{\text {in }} \\
& \mathrm{K}_{\mathrm{d} 1}=\mathrm{C}_{\text {out } 2} / \mathrm{C}_{\text {out } 1}=\mathrm{M}_{1} / \mathrm{M} \\
& \mathrm{K}_{\mathrm{d} 2}=\mathrm{C}_{\text {out } 2} / \mathrm{C}_{\text {out } 1}=\mathrm{M}_{2} / \mathrm{M}
\end{aligned}
$$

\section{と表される。}

仮想工程 2 後，2つの出力はそれぞれ別系統の流れで次の工程に入力されていくことになるが，排除品側の流 れ，いわゆる廃棄物処理コストも出力原価には含まれることになるので，2つの原価は最後に合算されると考えら れる.このとき, 排除品の単価はゼロと見なされるため, 排除品にかかったコストは製品の単価を上乗せするこ とで補う必要がある。不良率を見込んだ原価計算の方法と同様である.よって単価を上乗せするブロックの係数 は投入材料質量に対する製品質量の割合の逆数になる。この值を $\mathrm{K}_{\mathrm{u} 2}$ とすると，

$$
\mathrm{K}_{\mathrm{u} 2}=\mathrm{M} / \mathrm{M}_{1}=1 / \mathrm{K}_{\mathrm{d} 1}
$$

となる.

この時のブロック図は図4のようになる。工程Bは入力された材料を製品と排除品の2つに分け，それぞれが所 定の工程で処理を受けた後に合算し，単価を調整してひとつの出力とする形で表せる. 仮想工程2のように材料質

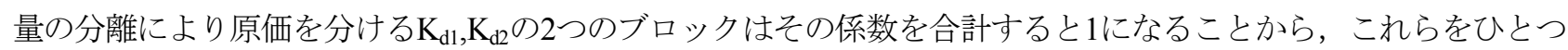
のグループとして捉え，質量分離ブロックと呼ぶことにする.つまり工程前後で質量が減少する工程は単価変更 ブロックと質量分離ブロックをつなげた形になる.

\section{$2 \cdot 4$ 工程の前後で質量が増加する場合}

最後に工程の前後で質量が増加する工程Cのブロック化を試みる. 例えば部品等が付加される組み立て工程な どが例として挙げられる. 投入材料の質量を $\mathrm{M}[\mathrm{kg}]$, 単価を $\mathrm{U}_{\mathrm{in}}[\mathrm{yen} / \mathrm{kg}]$ とし, 投入されるコストの合計をC $[\mathrm{yen}]$ と する. そして加えた部品の質量, 単価をそれぞれ $\mathrm{M}_{\mathrm{p}}[\mathrm{kg}], \mathrm{U}_{\mathrm{p}}[\mathrm{yen} / \mathrm{kg}]$ とすると, 入力原価 $\mathrm{C}_{\mathrm{in}}[\mathrm{yen}]$ と出力原価 $\mathrm{C}_{\text {out }}[\mathrm{yen}]$ は次のようになる。

$$
\begin{aligned}
& \mathrm{C}_{\text {in }}=M \cdot U_{\text {in }} \\
& C_{\text {out }}=M \cdot U_{\text {in }}+M_{p} \cdot U_{p}+C
\end{aligned}
$$



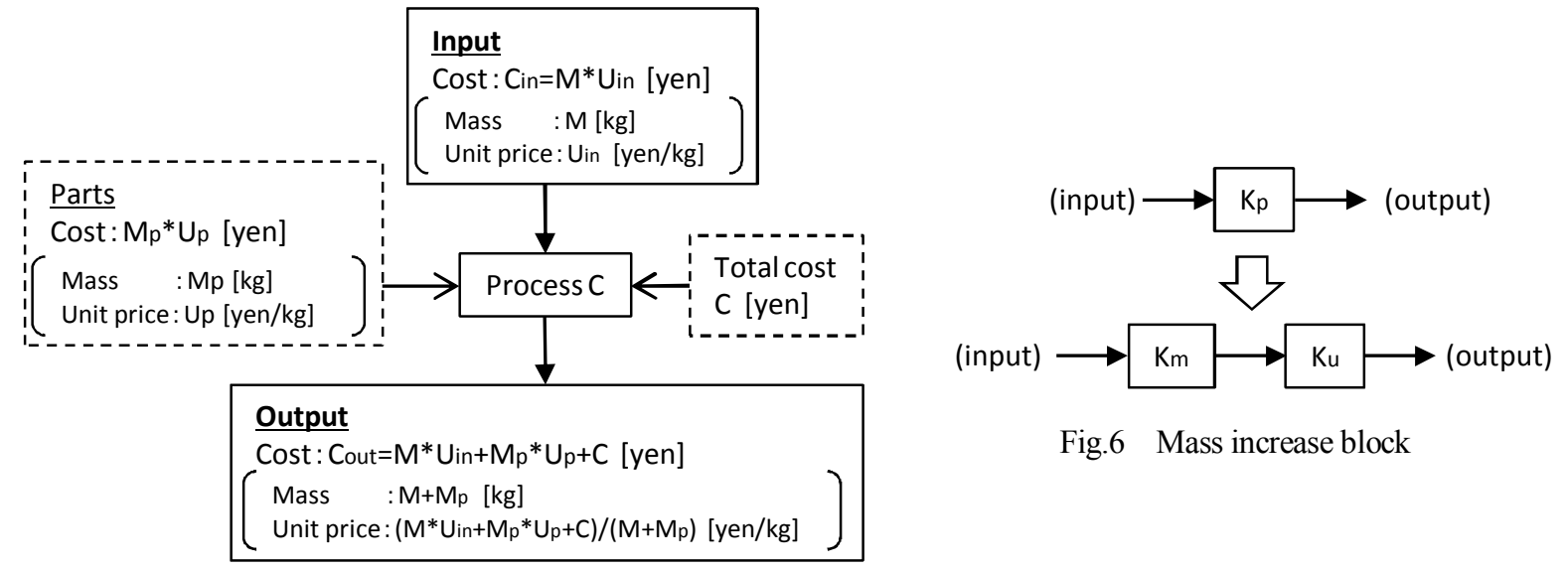

Fig.6 Mass increase block

Fig.5 Input and output for the process that increase mass

入出力の比 $\mathrm{K}_{\mathrm{p}}$ を取ると式(12)より

$$
\begin{aligned}
\mathrm{K}_{\mathrm{p}}=\mathrm{C}_{\mathrm{ou}} / \mathrm{C}_{\text {in }} & =\left(\mathrm{M} \cdot \mathrm{U}_{\text {in }}+\mathrm{M}_{\mathrm{p}} \cdot \mathrm{U}_{\mathrm{p}}+\mathrm{C}\right) /\left(\mathrm{M} \cdot \mathrm{U}_{\text {in }}\right) \\
& =1+\left(\mathrm{M}_{\mathrm{p}} \cdot \mathrm{U}_{\mathrm{p}}+\mathrm{C}\right) /\left(\mathrm{M} \cdot \mathrm{U}_{\text {in }}\right)
\end{aligned}
$$

となる.この時の概要を図5に示す． 1 個 $1 \mathrm{~kg}$ の材料に $0.1 \mathrm{~kg}$ の部品を 1 個組み付ける工程を考えた時, 材料 100 個の

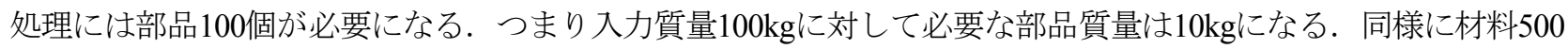
個 $500 \mathrm{~kg}$ 処理する時には部品は500個50kg投入することになる. よって大量生産の工程では付加される部品質量は 投入される材料質量に比例すると言える. この場合, 組立に要する作業時間も5倍になることから人件費も投入材 料質量に比例する. つまり, 付加される部品の質量 $\mathrm{M}_{\mathrm{p}}$ 及び投入コストCは投入質量 $\mathrm{M} に$ 比例し, それぞれの単価 $\mathrm{U}_{\mathrm{in}}, \mathrm{U}_{\mathrm{p}}$ は投入質量の影響は受けないと考えられるため, 工程 $\mathrm{C}$ も程 $\mathrm{A}$ と同様に投入質量にかかわらず入力を係数 倍して出力するブロックとして扱うことができる.この時の出力単価 $U_{\text {out }}$ は式(12)より

$$
\mathrm{U}_{\text {out }}=\mathrm{C}_{\text {out }} /\left(\mathrm{M}+\mathrm{M}_{\mathrm{p}}\right)=\left(\mathrm{M} \cdot \mathrm{U}_{\text {in }}+\mathrm{M}_{\mathrm{p}} \cdot \mathrm{U}_{\mathrm{p}}+\mathrm{C}\right) /\left(\mathrm{M}+\mathrm{M}_{\mathrm{p}}\right)
$$

となる．また，式(12),(14)より入出力の比 $\mathrm{K}_{\mathrm{p}}$ は

$$
\begin{aligned}
\mathrm{K}_{\mathrm{p}} & =\left(\mathrm{M} \cdot \mathrm{U}_{\text {in }}+\mathrm{M}_{\mathrm{p}} \cdot \mathrm{U}_{\mathrm{p}}+\mathrm{C}\right) /\left(\mathrm{M} \cdot \mathrm{U}_{\text {in }}\right) \\
& =\left\{\left(\mathrm{M}+\mathrm{M}_{\mathrm{p}}\right) / \mathrm{M}\right\} \cdot\left[\left(\mathrm{M} \cdot \mathrm{U}_{\text {in }}+\mathrm{M}_{\mathrm{p}} \cdot \mathrm{U}_{\mathrm{p}}+\mathrm{C}\right) /\left\{\left(\mathrm{M}+\mathrm{M}_{\mathrm{p}}\right) \cdot \mathrm{U}_{\text {in }}\right\}\right] \\
& =\left\{\left(\mathrm{M}+\mathrm{M}_{\mathrm{p}}\right) / \mathrm{M}\right\} \cdot\left(\mathrm{U}_{\text {out }} / \mathrm{U}_{\text {in }}\right)
\end{aligned}
$$

となる.工程前後での質量変化の比を $\mathrm{K}_{\mathrm{m}}$ とすれば

$$
\mathrm{K}_{\mathrm{m}}=\left(\mathrm{M}+\mathrm{M}_{\mathrm{P}}\right) / \mathrm{M}
$$

が成り立つため，式(6),(15),(16)より

$$
\mathrm{K}_{\mathrm{p}}=\mathrm{K}_{\mathrm{m}} \cdot \mathrm{K}_{\mathrm{u}}
$$

となる.

つまり工程Cは質量変更分と単価変更分をかけ合わせて算出される係数を入力原価にかけて出力としているこ とが分かる. 後述する制御工学の等価変換の継続結合を用いれば，質量変更と単価変更のブロックをつなげた形 で表せる.工程Cのブロック図を図6に示す. 


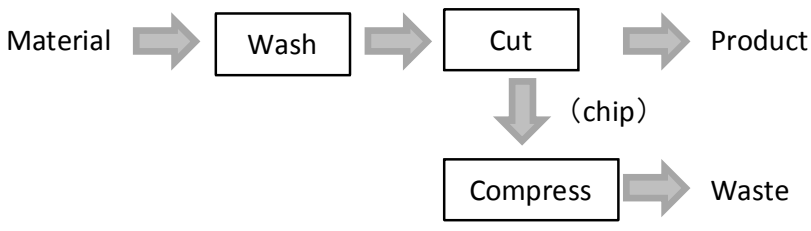

Fig.7 Example process

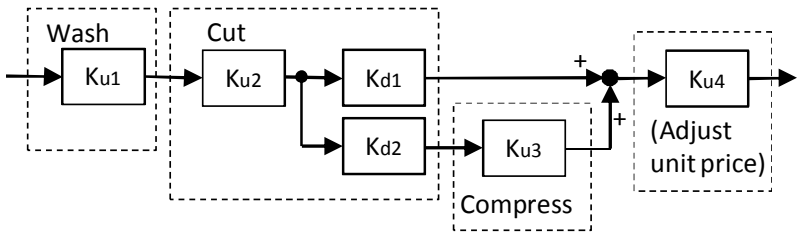

Fig.8 Example block diagram

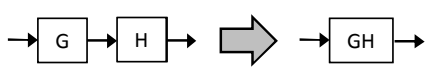

(1) Continuation

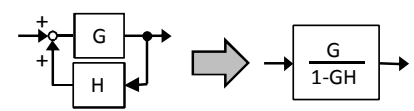

(3) Return

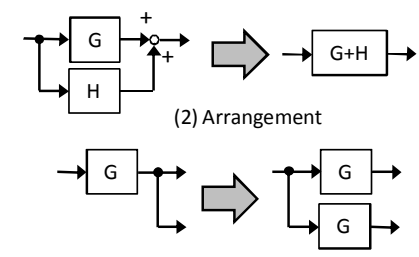

(4) Joint movement

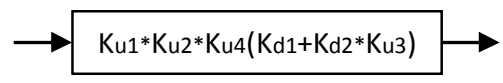

Fig.10 Consolidated block diagram

Fig.9 Equivalent transformations

\section{3. 製造プロセスのブロック図による表現と等価変換}

材料を洗浄した後切削し, 製品とするプロセスを例題として, 前章で述べたブロック化の手法によりブロック 図を作成する方法を述べる. 図7に例題とする切削プロセスの概要を示す.

はじめに材料が投入される洗浄工程は工程前後で材料の質量変化がないため，単価変更ブロックで表される. この出力が次の切削工程の入力となることから, 洗浄工程の出力と切削工程の入力を矢印で結ぶ. 次の切削工程

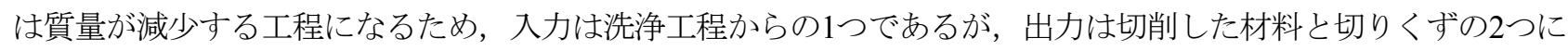
分かれる. 切りくずとして分離した出力はその次に質量変化のない圧縮工程に入力されるため, 単価変更ブロッ クが後ろに接続される. 図8にこのプロセスのブロック図を示寸.ここで, $\mathrm{K}_{\mathrm{u} 1}, \mathrm{~K}_{\mathrm{u} 2}, \mathrm{~K}_{\mathrm{u} 3}, \mathrm{~K}_{\mathrm{u} 4}$ はそれぞれ洗浄, 切削, 圧縮工程と廃棄物用コスト加算のための単価調整を表す単価変更ブロックの係数を表し， $\mathrm{K}_{\mathrm{d} 1}, \mathrm{~K}_{\mathrm{d} 2}$ は切削工程の質 量分離ブロックの係数を表している. 式(11)より

$$
\mathrm{K}_{\mathrm{u} 4}=1 / \mathrm{K}_{\mathrm{d} 1}
$$

の関係がある．また，質量分離ブロックの性質より

$$
\mathrm{K}_{\mathrm{d} 1}+\mathrm{K}_{\mathrm{d} 2}=1
$$

となっている.

制御工学ではブロック図を簡略化するため図9に示す等価変換の法則がある ${ }^{(14)}$.この法則を適用すると，図 $8 の$ ブロック図は図10のように集約できる. 出力原価は入力原価とブロックの係数の積になることから，このブロッ クの係数を比較することで出力原価の大小を判断できる. また，製造プロセス全体の係数を各工程のブロックの 係数を用いた数式で表していることから，プロセスの原価に及ぼす各工程の影響を試算することが容易である.

\section{4. 実際の製造プロセスへの適用例}

図 11 はある切削プロセスをブロック図化したものである. 初期洗浄から切削して切りくずを分離し, 磨いて再 洗浄，検查をして不良品を排除し，梱包・運搬するプロセスを表している.

従来の原価計算では製造プロセス内でかかったコスト全てを加算して評価するため, 各工程が最終原価に与え る影響を把握することは難しい. 図11のプロセスにおいて, 例えば検査工程での合格率を見直すことによって最 終的な出力原価を目標值まで低下させるという課題があった場合, 従来の方法では合格品と不合格品の仮定の物 


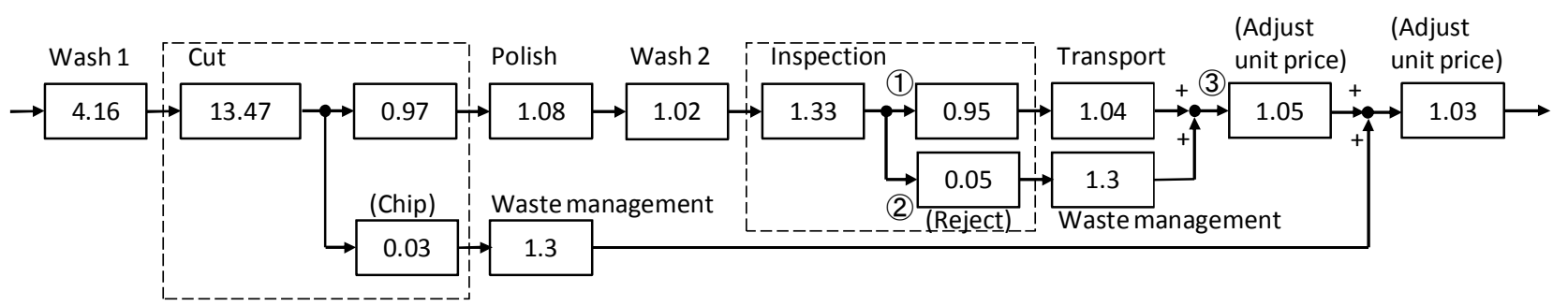

Fig.11 Cut process block diagram

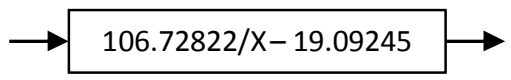

Fig.12 Consolidated block diagram

流量から算出される各工程のコストを足し合わせる作業を複数回行う必要がある。一方，この手法を用いれば検 查工程の係数を未知数として等価変換した方程式が利用できることにより，素早く合格率の目標值を見積ること ができる.

図11の検査工程での合格率をXとすれば図中の検査工程のブロック(1)の係数をX, (2)を1-X, (3)を1/Xとして等価 変換を実施できる．結果を図12に示す，元の工程の合格率は95\%であり，この時等価変換したプロセスのブロッ クの係数は93.25259である。これより原価を5\%低下させる合格率Xを求めるためには

$106.72822 / \mathrm{X}-19.09245=93.25259 \cdot(1-0.05)$

の式を解けばよい，式(20)よりXう0.9914が得られる．よって図11のプロセスでは検査工程での合格率を約 $99.1 \%$ にすれば原価を $5 \%$ 下げられることが算出できた.

\section{5. 環境配慮型製造プロセスへの応用}

\section{$5 \cdot 1 \quad$ リサイルエ程のブロック図化}

図7に示寸製造プロセスを図13に示寸様に再生工程を経て切りくずを再利用する形に変化させたと仮定する.再 生後, 切りくずは原料と同じ状態になって再度材料として投入されるが，もとの新規投入材料から洗浄，切削， 再生という複数の工程を経て作られたと考えられるため，新規投入材料に比べると単価が上がっている．しかし 最初の洗浄工程に導入される段階になると，再生材料も新規材料と全く同等のものとして扱われるため，その価 值も新規材料と同じと見なされる。つまり再生材料と新規材料との単価の差額分は目に見えない価値的な廃棄物 として捉える必要がある. 図14にこの時のブロック図を示す。この中で $\mathrm{K}_{\mathrm{e} 1}, \mathrm{~K}_{\mathrm{e} 2}$ で表されている単価分離ブロック が再生材料と新規材料の単価の差額分を分離する働きを表しているものである. 再生材料の単価はそこまでに通 過した単価変更ブロックの係数分だけ増加しているため, 新規材料と同じ単価とするためには単価変更ブロック 係数の積の逆数を掛ければよい.つまりこの例では

$$
\mathrm{K}_{\mathrm{e} 1}=1 /\left(\mathrm{K}_{\mathrm{u} 1} \cdot \mathrm{K}_{\mathrm{u} 2} \cdot \mathrm{K}_{\mathrm{u} 3}\right)
$$

の関係を持つ.また分離ブロックの性質から

$$
\mathrm{K}_{\mathrm{e} 1}+\mathrm{K}_{\mathrm{e} 2}=1
$$

の関係が成り立つ.このとき廃棄される $\mathrm{K}_{\mathrm{e} 2}$ 部分は物質的な廃棄物と同様にそのまま出力原価に加算されるものと 考えられる.

また，新規材料の投入量は再生材料分だけ少なくて済むため，その部分を係数 $\mathrm{K}_{\mathrm{m}}$ を持つ先頭の質量変更ブロッ クで表している．新規材料の投入量は製品となってこの系から出て行った分と等しくなるので, 


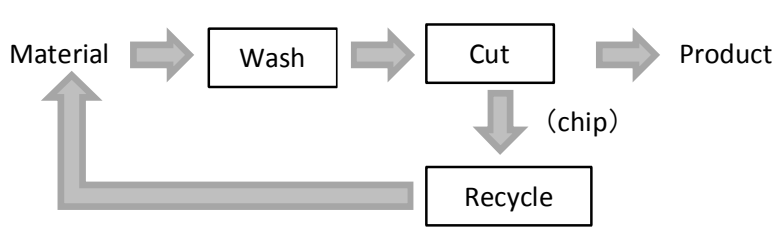

Fig.13 Recycle process

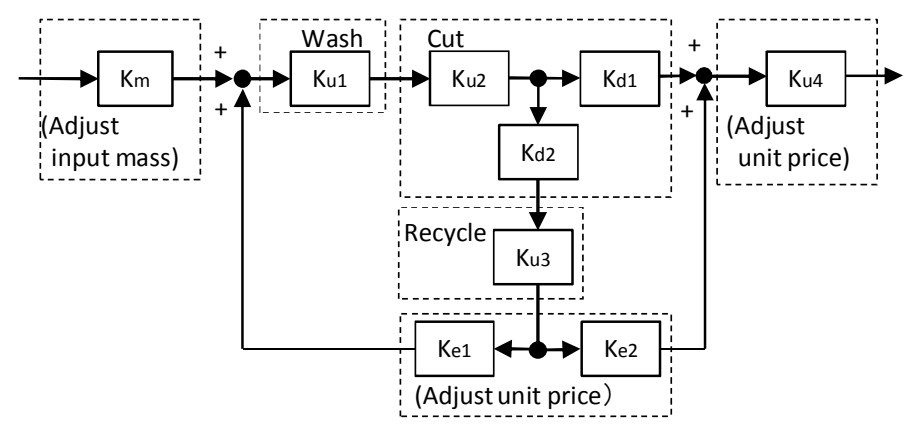

Fig.14 Recycle process block diagram

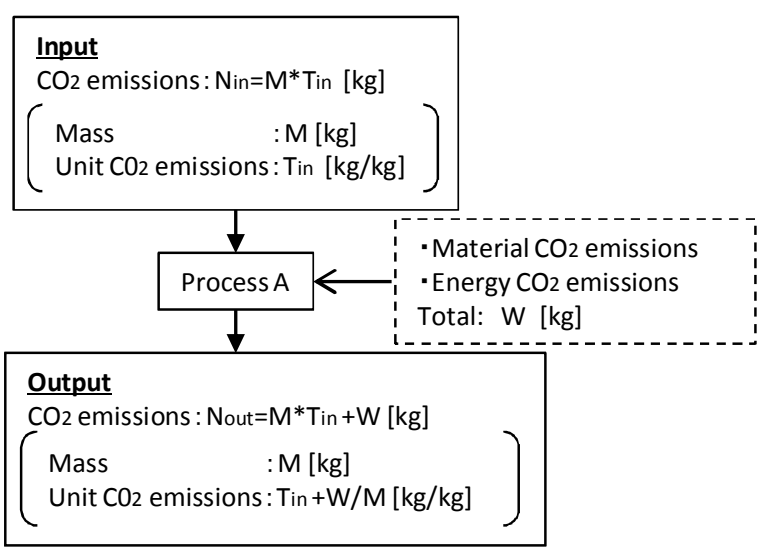

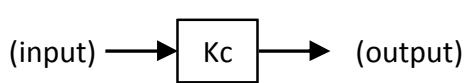

Fig.16 $\mathrm{CO}_{2}$ emissions block for the process that has no mass change

Fig.15 $\mathrm{CO}_{2}$ Input and output for the process that has no mass change

$$
\mathrm{K}_{\mathrm{m}}=\mathrm{K}_{\mathrm{d} 1}
$$

となる・

また，最後に質量分離ブロックで排除された分の単価調整のため，単価変更ブロック $\mathrm{K}_{\mathrm{u} 4}$ を配置している．式(11) と同様に

$$
\mathrm{K}_{\mathrm{u} 4}=1 / \mathrm{K}_{\mathrm{d} 1}
$$

という值を持つ。また質量分離ブロックの性質から

$$
\mathrm{K}_{\mathrm{d} 1}+\mathrm{K}_{\mathrm{d} 2}=1
$$

が成り立つ、等価変換と式(21),(22),(23),(24),(25)を用いると，図14のブロック図は

$$
\mathrm{K}=\mathrm{K}_{\mathrm{u} 1} \cdot \mathrm{K}_{\mathrm{u} 2}+\left(\mathrm{K}_{\mathrm{u} 1} \cdot \mathrm{K}_{\mathrm{u} 2} \cdot \mathrm{K}_{\mathrm{u} 3}-1\right)\left(\left(1 / \mathrm{K}_{\mathrm{d} 1}\right)-1\right)
$$

の值を持つブロックに集約される。このようにリサイクルプロセスにおいてもブロック図を適用できることが分 かる.

\section{$5 \cdot 2$ 製造プロセスの $\mathrm{CO}_{2}$ 排出量への応用}

前項までは原価に着目して製造プロセスをモデル化したが，同様の方法を用いて $\mathrm{CO}_{2}$ 排出量をブロック図でモ デル化できる. 原価の場合に用いた質量と単価の考え方を, 質量と単位質量当たりの $\mathrm{CO}_{2}$ 排出量に変えればよい. 
図15に工程の前後で材料の質量変化のない工程Aを例にした場合の概要を示す．投入材料の投入時までに排出し た単位質量当たりの $\mathrm{CO}_{2}$ 排出量を $\mathrm{T}_{\mathrm{in}}[\mathrm{kg} / \mathrm{kg}]$ 材料の質量を $\mathrm{M}[\mathrm{kg}]$ とすれば投入時の $\mathrm{CO}_{2}$ 排出量 $\mathrm{N}_{\mathrm{in}}[\mathrm{kg}]$ は

$$
\mathrm{N}_{\text {in }}=\mathrm{M} \cdot \mathrm{T}_{\text {in }}
$$

となる. そしてこの工程での投入材料, 投入エネルギーの $\mathrm{CO}_{2}$ 排出量の合計を $\mathrm{W}[\mathrm{kg}]$ とすればこの工程後の排出量 $\mathrm{N}_{\text {out }}[\mathrm{kg}]$ は式(27)より

$$
\mathrm{N}_{\text {out }}=\mathrm{N}_{\text {in }}+\mathrm{W}=\mathrm{M} \cdot \mathrm{T}_{\text {in }}+\mathrm{W}
$$

となる．入出力の比 $\mathrm{K}_{\mathrm{c}}$ とすると式(27)，(28)より

$$
\mathrm{K}_{\mathrm{c}}=\mathrm{N}_{\text {out }} / \mathrm{N}_{\text {in }}=\left(\mathrm{M} \cdot \mathrm{T}_{\text {in }}+\mathrm{W}\right) / \mathrm{M} \cdot \mathrm{T}_{\text {in }}=1+\mathrm{W} /\left(\mathrm{M} \cdot \mathrm{T}_{\text {in }}\right)
$$

となる. 大量生産の現場では投入された材料，エネルギーの量は原材料の質量に比例するので，工程Aでは入力 された材料の $\mathrm{CO}_{2}$ 排出量を $\mathrm{K}_{\mathrm{c}}$ 倍にして出力したと見なせる.この時のブロック図は図16のようになり，原価の場 合の単価変更ブロックと全く同様になることが分かる．重量分離ブロック等についても原価の場合と同様に考え られることから，ある製造プロセスの $\mathrm{CO}_{2}$ 排出量についてのブロック図を作成できる. 同様に水使用量や地球温 暖化ガスなど各工程で入力される質量に比例して作用寸る要素を取り上げれば，同様の方法でブロック図が作成 可能である.

\section{6. 結 語}

大量生産製造プロセスの材料の流れを質量で表し，原価を単位質量当たりの原価と材料の質量との積であると 捉えることにより，プロセス内の各工程は原価を操作する要素であると考えられることが分かった. 各工程は工 程前後で質量が変化なし, 減少する, 増加するの 3 つのパターンでブロック化できることを示した. また, 各工 程を表すブロックの入出力を接続することで，製造プロセスをブロック図で表すことができ，さらに等価変換を 実施することによってひとつのブロックに集約できることを示した．各工程が最終出力に及ぼす影響を把握する ことが可能になるため, 工程変更時の出力原価の試算が容易になる. また，同様の考え方で製造プロセスの二酸 化炭素排出量をブロック図化できることが分かった．環境配慮型製造プロセスを構築する際，工程を変更してコ スト，二酸化炭素排出量がどのように増減するか，容易にシミュレーションを実施することが可能となる.

\section{文献}

（1）山田秀，市川芳明，齊藤潔，佐藤孝夫，環境配慮設計の要求事項(2011), p. 9, 日本規格協会.

(2) Masui, K., "Current Status of Environmentally Conscious Design Among Japanese Manufacturers", International Journal of Automation Technology, Vol.3, No.1(2009), pp.19-25.

(3) 堂脇清志, 伊澤智也, 坂本和之, “Bio-H2 による燃料電池携帯電話の $\mathrm{CO}_{2}$ 評価”, 日本 LCA 学会誌, Vol.6,No.3(2010),pp259-269.

（4）中神好正, 北島政充, 生沼一幸, 濱川雅之, “ライフサイクルを通じた製品の環境配慮”, FUJITSU, Vol.62,No.6(2011),pp680-687.

(5) 稲葉敦, LCA の実務(2005), p.1, 産業管理協会.

(6) LOW BIHONG， 木下裕介, 福重真一, 梅田靖, 鈴木敦, 川邊隆男, “重みつき環境配慮設計チェックリストの作 成手法に関する研究”, 精密工学会誌, Vol.76, No.11 (2010), pp.1288-1292.

(7) 伊坪徳宏, “ライフサイクル視点に基づく環境影響評価”, 精密工学会誌, Vol.75, No.9(2009), pp.1062-1067. 
（8）佐久間徹，日比野浩典，山口誠，“生産システム設計・改善時における生産性と消費エネルギ量のシミュレーショ ンシステム”，日本機械学会論文集 C, Vol.79,No.798(2013),pp.178-189.

（9）成田浩久, 河村浩志, 則久孝志, 陳連, 藤本英雄, 長谷部孝男 “工作機械による加工の環境負荷予測システムの開 発”，日本機械学会論文集 C 編，Vo71,No.704(2005),pp.1392-1398.

（10）赤松俊昌，小田昇，“水再利用をめざした産業排水処理システム”，日立評論，Vol.94,No.12(2012),pp852-853.

（11）小倉滋，手塚宏之，弓手崇生，田村望，“JFE スチールにおける環境保全と省エネルギーへの取組み”，JFE技報， No.32(2013),pp1-7.

（12）速水直哉, 田家真紀子, “環境負荷を大幅に低減する半導体のレジスト除去技術”, 東芝レビュー, Vol.64,No.5(2009),pp.38-41.

(13）國部克彦，実践マテリアルフローコスト会計(2008)，p.3，産業環境管理協会.

(14) 福島弘毅, 制御工学基礎論(1992), p.37, 丸善. 